\title{
Retraction Note: Clinical application of contrast enhanced ultrasound to diagnose benign prostatic hyperplasia
}

\author{
Jingfang Shi ${ }^{*}$, Xiaohua Yin ${ }^{2 *}$, Rong $X u^{1}$, Yingchun Wang ${ }^{1}$, Lin $\operatorname{Jin}^{1}$ and Weiwei Gao
}

\section{Retraction}

The Publisher and Editor regretfully retract this article [1] because the peer-review process was inappropriately influenced and compromised. As a result, the scientific integrity of the article cannot be guaranteed. A systematic and detailed investigation suggests that a third party was involved in supplying fabricated details of potential peer reviewers for a large number of manuscripts submitted to different journals. In accordance with recommendations from COPE we have retracted all affected published articles, including this one. It was not possible to determine beyond doubt that the authors of this particular article were aware of any third party attempts to manipulate peer review of their manuscript.

\section{Update posted $\left\{2^{\text {nd }}\right.$ July, 2015 $\}$}

BioMed Central has been informed of the outcome of a thorough investigation by the institution. That investigation found that the authors of this article [1] intended to purchase language editing services for their manuscript only and did not participate in influencing the peer review process. The institution has taken further steps to educate their researchers regarding best practice in research and publication ethics.

Received: 3 March 2015 Accepted: 3 March 2015

Published online: 26 March 2015

\section{Reference}

1. Shi J, Yin X, Xu R, Wang Y, Jin L, Gao W. Clinical application of contrast enhanced ultrasound to diagnose benign prostatic hyperplasia. Diagn Pathol. 2013;9:133.

\footnotetext{
*Correspondence: shijingfangpia@hotmail.com; yinxiaohuahappy@hotmail.com 'Department of Ultrasound, Jiading Center Hospital, Shanghai 201800, China ${ }^{2}$ Department of Radiology, Jiading Center Hospital, No.1 Chengbei Road, Jiading District, Shanghai 201800, China
}

\section{Submit your next manuscript to BioMed Central and take full advantage of:}

- Convenient online submission

- Thorough peer review

- No space constraints or color figure charges

- Immediate publication on acceptance

- Inclusion in PubMed, CAS, Scopus and Google Scholar

- Research which is freely available for redistribution

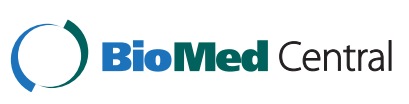

(c) 2015 Shi et al.; licensee BioMed Central. This is an Open Access article distributed under the terms of the Creative Commons Attribution License (http://creativecommons.org/licenses/by/4.0), which permits unrestricted use, distribution, and reproduction in any medium, provided the original work is properly credited. The Creative Commons Public Domain Dedication waiver (http://creativecommons.org/publicdomain/zero/1.0/) applies to the data made available in this article unless otherwise stated. 